\title{
TEKNOLOGI PENANGANAN DAN TRANSPORTASI LOBSTER AIR TAWAR
}

\author{
Th. Dwi Suryaningrum, Syamdidi dan Diah Ikasari*)
}

\begin{abstract}
ABSTRAK
Lobster air tawar yang diperdagangkan dalam keadaan hidup, memerlukan serangkaian kegiatan yang meliputi penanganan pascapanen, penampungan dan pengemasan sebelum dilakukan transportasi. Penanganan pascapanen ditujukan untuk sortasi, dengan memisahkan lobster berdasarkan ukuran dan kebugarannya. Penampungan dilakukan bila lobster yang akan dipasarkan jumlahnya tidak mencukupi atau lobster perlu dibugarkan terlebih dahulu sebelum dikirim. Penampungan dapat dilakukan dengan menggunakan rak bertingkat yang dilengkapi dengan sistem filtrasi dengan sistem aliran tertutup. Lobster sebelum dikirim dilakukan imotilisasi dengan suhu dingin $\left(12^{\circ} \mathrm{C}\right)$, kemudian dikemas dalam plastik mika yang pada bagian dasarnya diberi spon basah. Plastik mika kemudian dimasukkan ke dalam kotak styrofoam yang pada bagian dasar dan atasnya diberi es yang dibungkus dalam plastik. Kotak styrofoam kemudian direkatkan dengan lakban dan dimasukkan ke dalam karton untuk dikirim. Dengan kemasan seperti ini transportasi lobster air tawar dapat dilakukan sampai dengan 6 hari dengan sintasan $97 \%$. Ketahanan lobster yang cukup lama di luar media memungkinkan lobster dapat diekspor dalam keadaan hidup ke berbagai negara dimana peluang pasar lobster air tawar masih sangat terbuka.
\end{abstract}

KATA KUNCI: teknik penanganan, lobster air tawar, transportasi

\section{PENDAHULUAN}

Lobster air tawar atau yang sering disingkat dengan istilah LAT termasuk dalam kelompok udang air tawar yang aslinya ditemukan di danau, rawa, sungai atau kolam air tawar di daerah Papua atau Queensland, Australia. Lobster ini telah berhasil dibudidayakan di beberapa daerah antara lain Yogyakarta, Jawa Tengah, Jawa Barat, Jawa Timur dan DKI. Beberapa jenis yang telah dibudidayakan yaitu jenis red claw atau capit merah (Cherax quadricarinatus), Cherax albertisi, Cherax lorentzi, Cherax monticola, Cherax tenuimatus dan jenis Procambarus clarkia. Dari semua jenis lobster di atas, red claw yang paling banyak dibudidayakan. Red claw sebenarnya bukan lobster asli Indonesia melainkan berasal dari indukan yang diimpor dari Queensland Australia. Sedangkan Cherax albertisi merupakan lobster asli Indonesia yang berasal dari Papua.

Pada awalnya lobster air tawar dibudidayakan untuk tujuan sebagai ikan hias, karena bentuknya yang unik dan warnanya yang menarik. Namun akhirakhir ini budidaya lobster sudah mengarah kearah konsumsi, mengingat budidayanya yang lebih mudah dibandingkan dengan udang galah atau udang lainnya. Lobster air tawar memiliki ketahanan hidup yang lebih kuat, bahkan dalam lingkungan yang ekstrim sekalipun. Pertumbuhan lobster juga relatif cepat, untuk mencapai ukuran konsumsi dibutuhkan waktu antara 3 sampai 12 bulan tergantung dari ukuran yang diinginkan dan kondisi iklim tempat lobster dibudidayakan (Anon., 2007). Di samping itu, teknik budidaya yang tidak sulit serta harga tinggi yang hampir menyamai lobster air laut, memungkinkan bagi lobster air tawar untuk menjadi produk unggulan. Kelebihan lobster air tawar dibandingkan dengan produk perikanan lainnya adalah lobster ini dapat diperdagangkan dalam keadaan hidup, dapat dikemas tanpa menggunakan air dan sampai di tempat tujuan dalam kondisi tetap bugar (Lawrence, 2001). Di samping itu, lobster mempunyai tekstur daging yang lunak dengan rasa hampir sama dengan lobster air laut sehingga dapat digunakan sebagai hidangan yang prestisius di hotel-hotel dan restoran.

Budidaya lobster air tawar dapat dilakukan dengan menggunakan kolam, bak semen atau bak fiber glass yang dilengkapi dengan aerasi. Lobster air tawar akan tumbuh dengan cepat di dalam kolam air mengalir dimana sirkulasi air dan oksigen terjadi terus menerus. Pembesaran lobster sangat tergantung dari kualitas air, oksigen terlarut, suhu, pakan, adanya pelindung dan kepadatan lobster. Kadar oksigen terlarut sebaiknya berkisar antara 6-8 mg/L, namun lobster dapat hidup lama dengan kadar oksigen kurang dari $6 \mathrm{mg} / \mathrm{L}$. Derajat asam $(\mathrm{pH})$ air untuk pertumbuhan lobster berkisar antara 7-8, jika $\mathrm{pH}$ kurang dari kisaran nilai tersebut lobster akan mengalami stres. Suhu optimal untuk budidaya lobster berkisar antara $24-28^{\circ} \mathrm{C}$. Lobster air tawar dapat hidup pada kolam

\footnotetext{
*) Peneliti pada Balai Besar Riset Pengolahan Produk dan Bioteknologi Kelautan dan Perikanan
} 
dengan salinitas air kurang dari 8 per mil. Lobster air tawar bersifat omnivora, yang makan tumbuhtumbuhan dan binatang serta bersifat noktural yang hidup aktif pada malam hari. Oleh karena itu lobster lebih menyukai kolam yang berdasar lumpur atau jika menggunakan bak semen adanya shelter berupa potongan pipa plastik diperlukan dalam pembesaran lobster. Produksi budidaya lobster air tawar secara intensif dapat mencapai 2 ton/ha/th, namun dalam kolam biasa produksi lobster hanya berkisar antara $600 \mathrm{~kg} / \mathrm{ha} /$ th (Morrissy, 1992).

Australia merupakan salah satu negara yang telah berhasil membudidayakan lobster air tawar secara intensif. Saat ini $70 \%$ dari produksinya diekspor ke Eropa dan Amerika dan sisanya untuk pasar lokal ( Lawrence, 2001). Pasar lobster air tawar sebetulnya masih sangat terbuka, sehingga peluangnya dapat dimanfaatkan. Mengingat budidayanya yang relatif mudah, budidaya lobster air tawar saat ini sedang dilakukan di tambak udang di daerah Tuban, Jawa Timur. Jika budidaya ini dapat berhasil, tidak tertutup kemungkinan bahwa lobster air tawar nantinya dapat menjadi primadona seperti halnya udang windu. Selama ini pasar lobster air tawar ukuran konsumsi baru untuk restoran-restoran yang sudah tersebar di Jakarta, Bandung dan Yogyakarta. Namun apabila produksi lobster air tawar sudah melimpah, maka pasar luar negeri untuk ekspor lobster air tawar perlu dijajaki.

Berikut beberapa hal yang berkaitan dengan teknik penanganan dan transportasi lobster air tawar untuk ekspor :

\section{Penanganan Pascapanen}

Segera setelah lobster dipanen dicuci dengan air mengalir dalam bak penampungan selama 24 jam untuk menghilangkan kotoran terutama kotoran yang masuk ke dalam karapas, yang dapat menyebabkan infeksi insang selama transportasi. Lobster air tawar bisa dipanen sesuai dengan ukurannya, semakin besar ukurannya semakin mahal harga lobsternya. Lobster ukuran kecil dapat dipanen setelah 6 bulan benih ditebarkan, sedangkan untuk mencapai ukuran jumbo yang beratnya dapat mencapai $500 \mathrm{~g}$ dibutuhkan waktu 2 tahun. Lobster kemudian dipisahkan berdasarkan berat dan kualitasnya. Di pasaran ada 6 ukuran lobster yang diperdagangkan yaitu ukuran kecil (35-50g), ukuran medium (50-70 g), ukuran besar (70-90 g), ukuran ekstra besar (90$120 \mathrm{~g}$ ), ukuran XX (120-150g) dan ukuran jumbo (lebih dari $150 \mathrm{~g}$ ). Lobster air tawar hidup yang akan dikirim harus dalam keadaan bugar, sehat, kaki lengkap, tidak sedang ganti kulit (moulting). Lobster yang sedang moulting karapasnya lunak dan daya tahannya lemah, sehingga peluang kematiannya selama transportasi sangat tinggi. Cara pemeriksaan lobster yang sehat dilakukan dengan mengamati aktivitas lobster dan warna cangkangnya. Lobster yang sehat memiliki cangkang berwarna hijau kebiruan dan mempunyai respon yang sensitif terhadap rangsangan yang diberikan, seperti meloncat ke belakang dengan cepat bila disentuh. Pada saat diangkat lobster akan meronta-ronta dengan kuat. Sedangkan lobster yang kurang bugar ditandai dengan respon yang kurang cepat terhadap rangsangan yang diberikan, diam ketika diangkat, kaki jalan dan kaki renang lemah. Lobster ini sebaiknya tidak dikemas, karena akan mengalami kematian selama transportasi.

\section{Sistem Penampungan Lobster}

Penampungan diperlukan apabila lobster yang dipasarkan tidak langsung dikirim ke konsumen, atau jumlah lobster yang hendak dijual belum mencukupi sehingga dikumpulkan terlebih dahulu dalam bak penampungan. Adakalanya bak penampung yang dibuat digunakan untuk membesarkan lobster yang baru menetas menjadi bibit dengan ukuran $2 \mathrm{~cm}$. Bak penampung lobster dapat berupa bak semen yang permanen atau bak fiber glass atau akuarium yang berukuran besar. Hal paling penting yang harus diperhatikan selama penampungan adalah kualitas air, kelarutan oksigen, $\mathrm{pH}$ dan suhu air selama penampungan. Jika kondisi air selama penampungan optimal, maka akan diperoleh lobster yang sehat dan bugar. Fasilitas penampungan yang dilengkapi dengan sistem filtrasi dapat menjaga kondisi mutu air tetap baik. Sistem filtrasi ini dapat dibuat dari bak kaca yang disekatsekat sedemikian rupa sehingga air dapat mengalir dari atas dan bawah sekat secara bergantian. Ke dalam sistem filtrasi tersebut dimasukkan koral atau batu karang sebagai bahan filtrasi. Dengan sistem filtrasi ini mutu air dapat terjaga dengan baik, tanpa harus mengganti air, lobster tetap sehat selama penampungan atau bahkan penampungan tersebut dapat dimanfaatkan untuk pembesaran lobster. Bagi penampung yang lahannya sempit, penampungan dengan rak bertingkat yang dilengkapi dengan sistem filtrasi dapat menampung lobster dalam jumlah banyak tanpa harus menggunakan lahan yang luas (Gambar 1). Hasil penelitian menunjukkan bahwa rak penampung bertingkat dengan jumlah rak 3 susun yang dilengkapi dengan sistem filtrasi dapat menampung lobster dengan waktu lebih dari 6 bulan tanpa penggantian air (Suryaningrum et al., 2001). Kelebihan dari sistem penampungan seperti ini adalah dengan ruang yang terbatas dapat menampung lobster air tawar dengan kepadatan yang tinggi dengan waktu yang lama. Hal penting yang perlu diperhatikan selama penampungan dalam jangka 


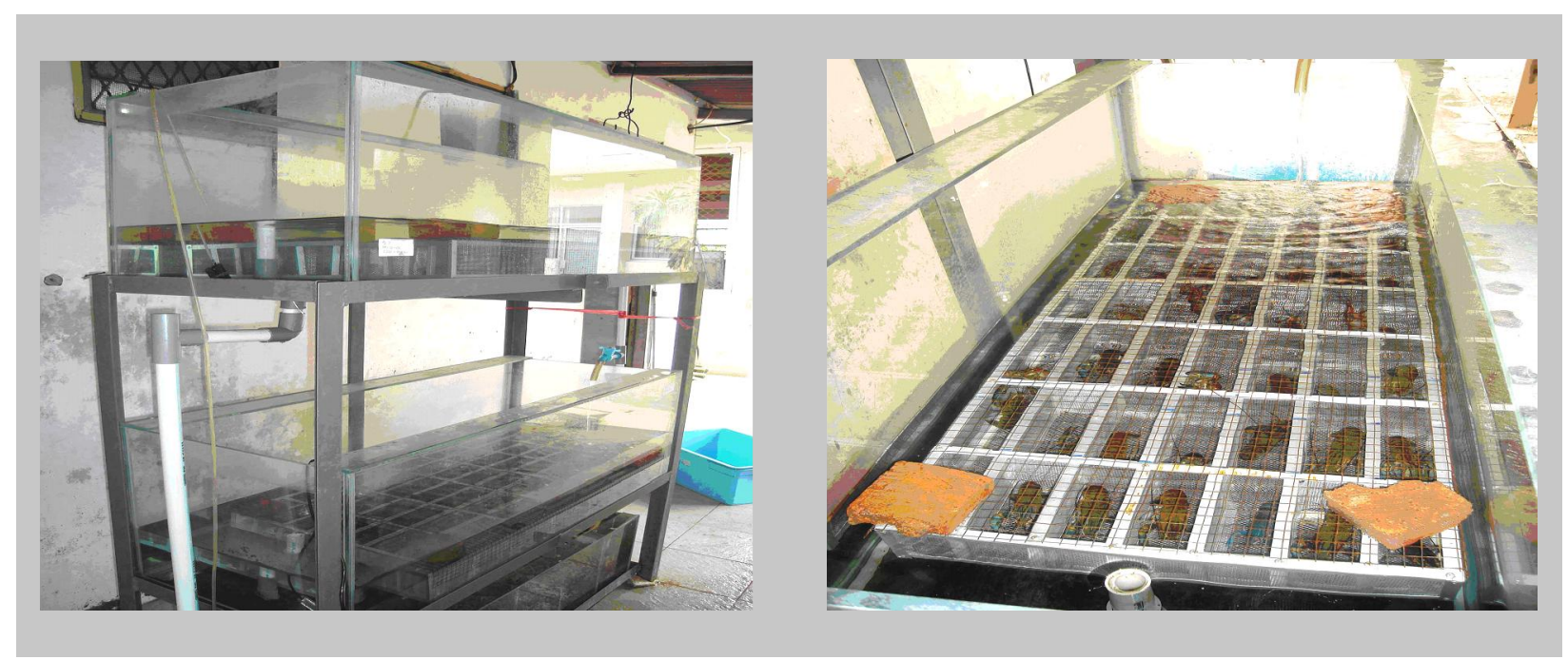

Gambar 1. Penampungan/pembesaran lobster air tawar menggunakan rak bertingkat dengan sistem sel.

waktu yang lama adalah ketika lobster mengalami moulting. Lobster merupakan binatang yang bersifat kanibal, sehingga pada saat moulting lobster sangat lemah dan sering sekali dimakan oleh lobster lainnya. Untuk mengatasi hal tersebut penampungan dengan sistem sel dapat mengurangi kematian lobster akibat sifat kanibalisme lobster atau dalam bak penampung diberi shelter berupa potongan pralon, sehingga lobster yang sedang moulting dapat bersembunyi di dalam pralon. Selama penampungan lobster air tawar diberi pakan berupa pelet dengan jumlah pakan sebanyak $3 \%$ dari berat lobster yang ditampung.

\section{Aktivitas dan Metabolisme Lobster Air Tawar pada Suhu Dingin}

Suhu dingin merupakan salah satu kunci dalam transportasi ikan hidup, pada kondisi ini tingkat metabolisme dan respirasi sangat rendah sehingga ikan/krustasea dapat diangkut dengan waktu yang lama dengan kelulusan hidup yang tinggi (Berka, 1986). Oleh karena itu informasi aktivitas dan metabolisme lobster pada berbagai suhu rendah perlu diketahui sebagai dasar untuk transportasi lobster hidup. Sebelum ditransportasi lobster dikondisikan imotil (tidak bergerak) dengan menggunakan suhu rendah sebagai suhu shock, demikian juga suhu media yang digunakan selama transportasi seharusnya berkisar pada suhu dimana lobster berada dalam metabolisme basal. Imotilisasi dengan suhu dingin merupakan cara yang paling efektif, ekonomis dan aman dalam mempersiapkan transportasi lobster air tawar. Hasil penelitian Wibowo et al. (2005), memberikan informasi mengenai perubahan fisiologis lobster air tawar pada berbagai suhu. Informasi tersebut digunakan untuk menentukan suhu imotil/shock dan suhu media selama transportasi. Adapun respon fisiologis terhadap penurunan suhu yang dilakukan secara bertahap dapat dilihat pada Tabel 1 .

Imotilisasi dilakukan untuk menekan aktivitas lobster sehingga pada saat lobster dikemas tidak menggigit dan mudah ditangani. Selain itu juga dapat menekan proses metabolisme selama transportasi. Imotilisasi yang dilakukan pada suhu $12-14^{\circ} \mathrm{C}$ selama 30-45 menit, menyebabkan lobster diam, kaki renang dan kaki jalan tidak bergerak dan mudah untuk dikemas. Pada dasarnya, imotilisasi dapat dilakukan dengan 2 metode yaitu metode penurunan suhu secara bertahap maupun secara langsung. Imotilisasi dengan penurunan suhu secara bertahap dilakukan dengan cara menurunkan suhu media air dari suhu air normal (suhu kamar) ke suhu dimana lobster mengalami imotil yaitu sekitar suhu $12-14^{\circ} \mathrm{C}$ (Suryaningrum et al., 2006). Penurunan dilakukan dengan menambahkan air dingin ke dalam media lobster secara perlahan-lahan, sehingga suhu yang diinginkan tercapai. Setelah suhu imotilnya tercapai lobster dibiarkan selama 30-45 menit sehingga aktivitas lobster diam. Lobster dikatakan imotil bila diangkat diam, kaki jalan dan kaki renang diam, dan mudah dikemas. Dengan metode imotilisasi ini lobster dapat ditransportasikan selama 6 hari dengan kelulusan hidup 97\% (Suryaningrum et al., 2006).

Sedangkan imotilisasi dengan metode langsung dilakukan dengan cara memasukkan lobster air tawar ke dalam air yang suhunya telah diatur sekitar 12$14^{\circ} \mathrm{C}$. Pada saat lobster dimasukkan ke dalam air reaksi lobster akan panik dan berenang sangat cepat dengan gerakan mundur. Proses panik ini terjadi sekitar 1-2 menit, kemudian lobster rebah atau diam tidak bergerak. Lobster dibiarkan selama 30-45 menit, untuk menjaga kenaikan suhu selama imotil ke dalam 
Tabel 1. Respon aktivitas fisiologi lobster air tawar pada berbagai suhu

\begin{tabular}{|c|c|c|c|}
\hline No & Suhu $\left({ }^{\circ} \mathrm{C}\right)$ & Perubahan aktivitas & Kriteria \\
\hline 1 & $30.4-25.4$ & $\begin{array}{l}\text { Pada suhu ini lobster bergerak aktif, kaki jalan, kaki } \\
\text { renang, dan chelliped (capit) bergerak aktif, lobster } \\
\text { cenderung bergerombol }\end{array}$ & Aktivitas normal \\
\hline 2 & $25.4-19.4$ & $\begin{array}{l}\text { Aktivitas lobster mulai berkurang, kaki jalan, kaki } \\
\text { renang dan chelliped bergerak perlahan-lahan, ekor } \\
\text { melipat ke dalam, lobster cenderung diam }\end{array}$ & Tenang \\
\hline 3 & $19.6-15.4$ & $\begin{array}{l}\text { Lobster gelisah, } 1-2 \text { ekor bergerak tidak beraturan } \\
\text { dengan menyentak-nyentakan tubuhnya mundur } \\
\text { kebelakang. Setelah panik lobster tenang kembali, } \\
\text { respon terhadap rangsangan lemah }\end{array}$ & Panik \\
\hline 4 & $15.4-12.9$ & $\begin{array}{l}\text { Lobster mulai hilang keseimbangan, gerakan lobster } \\
\text { lemah, respon terhadap rangsangan lemah, ketika } \\
\text { posisi tubuh dibalik tidak dapat tegak kembali }\end{array}$ & Awal disorientas \\
\hline 5 & $12.9-10.4$ & $\begin{array}{l}\text { Lobster hilang keseimbangan, posisi tubuh } \\
\text { rebah/terbalik, kaki jalan dan kaki renang diam }\end{array}$ & Disorientasi \\
\hline 6 & $10.4-9.8$ & $\begin{array}{l}\text { Keseimbangan lobster tidak ada, posisi tubuh terbalik, } \\
\text { kaki jalan, kaki renang dan chelliped kaku tidak } \\
\text { bergerak, ekor melipat ke arah abdomen. Respon } \\
\text { terhadap rangsangan tidak ada }\end{array}$ & Pingsan \\
\hline
\end{tabular}

Sumber : Wibowo et al. (2005)

media ditambah air dingin sehingga suhu imotilnya terjaga. Dengan metode imotilisasi seperti ini lobster dapat ditransportasikan selama 6 hari dengan kelulusan hidup $100 \%$ lebih baik dan lebih praktis dibandingkan dengan metode imotilisasi secara bertahap (Suryaningrum et al., 2006).

Suhu kemasan yang optimum untuk transportasi lobster sebaiknya berkisar antara $15-20^{\circ} \mathrm{C}$, pada suhu ini lobster dalam kondisi tenang, sehingga aktivitas lobster tidak banyak bergerak. Suhu kemasan juga tidak boleh terlalu dingin atau kurang dari $12^{\circ} \mathrm{C}$, jika lobster berada pada suhu terlalu dingin dalam jangka waktu yang lama maka lobster akan mengalami eklamsia yang dapat menyebabkan kematian.

\section{Pengemasan dan Transportasi Lobster Air Tawar}

Salah satu kelebihan dari lobster air tawar dibandingkan dengan lobster air laut adalah kemampuan hidup di luar media air dalam lingkungan yang lembab dalam waktu yang lebih lama. Oleh karena itu lobster air tawar diperdagangkan hidup dan transportasi dilakukan dengan sistem kering. Media yang digunakan untuk transportasi harus bersifat lembab, dengan suhu di dalam kemasan dipertahankan berkisar antara $12,9^{\circ} \mathrm{C}-25,4^{\circ} \mathrm{C}$. Dalam kondisi ini transportasi lobster lebih lama dan kelulusan hidupnya tinggi.

Bahan pengemas yang digunakan untuk transportasi lobster air tawar terdiri dari kemasan luar berupa karton, dan kemasan dalam berupa kotak styrofoam, kotak plastik mika, lakban dan es dalam kantong plastik untuk mempertahankan suhu kemasan. Kemasan yang digunakan untuk transportasi lobster air tawar biasanya berupa sistem sel, yaitu dengan cara memasukkan lobster ke dalam kotak plastik mika kemudian dimasukkan ke dalam kotak styrofoam. Pada bagian dasar kotak plastik mika diberi alas berupa media basah untuk mempertahankan kelembaban selama transportasi. Media tersebut harus memiliki daya serap air yang tinggi, mampu mempertahankan suhu rendah dalam waktu yang relatif lama serta kondisi media yang stabil. Media yang digunakan untuk mengangkut lobster dapat berupa kertas koran, sabut kelapa, batang pisang kering atau spon. Namun media yang paling praktis, ekonomis, stabil dan memiliki daya serap air dan dapat mempertahankan kelembaban paling baik adalah spon. Spon yang akan digunakan sebagai media dipotong-potong sesuai dengan ukuran kotak plastik mika, kemudian dicuci dan direndam dalam air dingin (suhu $12-14^{\circ} \mathrm{C}$ ) selama $15-30$ menit. Spon kemudian digunakan untuk mengalasi kotak 
plastik mika, dan lobster yang telah imotil dimasukkan ke dalam kotak plastik mika. Kotak plastik mika yang berukuran $25 \times 15 \times 6 \mathrm{~cm}$ dapat diisi 6-7 ekor lobster (Gambar 2). Plastik mika yang sudah diisi lobster kemudian dimasukkan ke dalam kotak styrofoam yang berukuran $60 \times 40 \times 40 \mathrm{~cm}$ yang didasarnya telah diberi 3 buah es yang

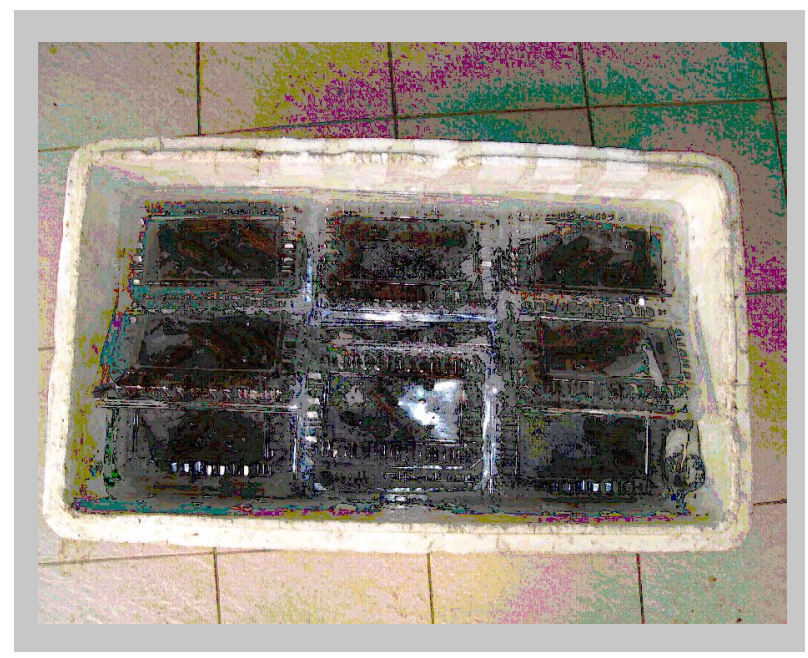

Gambar 2. Kemasan sistem sel lobster air tawar selama transportasi.

dibungkus plastik yang beratnya masing-masing \pm $70 \mathrm{~g}$ dan disusun secara diagonal. Masing-masing kotak styrofoam dapat diisi 6 buah plastik mika, kemudian di atas mika diberi es yang dibungkus plastik yang disusun secara diagonal juga. Kotak styrofoam kemudian ditutup dan direkatkan dengan lakban dan dimasukkan ke dalam karton. Hal yang perlu diperhatikan dalam pengemasan lobster adalah penggunaan es untuk mempertahakan suhu media. Apabila jumlah es terlalu banyak, maka suhu di dalam kemasan akan turun sehingga suhu dalam kotak styrofoam kurang dari $12^{\circ} \mathrm{C}$, apalagi bila suhu ruang selama transportasi dilengkapi dengan pendingin (AC) seperti suhu di dalam ruang pesawat. Kondisi ini menyebabkan lobster sekarat dan mengalami eklamsia yang berakibat kepada kematian. Pada dasarnya lobster sangat tahan pada lingkungan yang ekstrim. Hasil penelitian Suryaningrum et al. (2006) menunjukkan bahwa transportasi lobster ke Lampung dimana suhu di dalam kemasan selama perjalanan Jakarta-Lampung mencapai $32,9^{\circ} \mathrm{C}$, lobster dapat bertahan hidup sampai 6 hari dengan sintasan hidup 97\% dan lobster sehat setelah dibugarkan kembali. Pada dasarnya lobster dapat bertahan tanpa diberi pakan selama 7 hari, sehingga lobster dapat ditransportasi sampai 7 hari. Namun semakin lama waktu transportasi resiko kematian lobster semakin tinggi dan penyusutan semakin besar.

Pembugaran kembali lobster dilakukan secara bertahap, yaitu lobster diangin-anginkan terlebih dahulu selama 3-5 menit agar amonia yang terjadi selama transportasi menguap. Kemudian lobster dimasukkan ke dalam air dengan ketinggian air setengah dari badan lobster dan lobster dibiarkan selama 1 jam, untuk menghilangkan kotoran berupa isi perut selama transportasi. Selanjutnya lobster baru ditampung dalam bak penampung yang sebenarnya.

Selama transportasi, lobster mengalami penyusutan berat, semakin lama transportasi semakin besar penyusutannya. Idealnya dalam pemasaran lobster penurunan bobot tidak boleh lebih dari $5 \%$, karena akan berdampak langsung terhadap menurunnya harga jual lobster. Hasil penelitian terhadap Cherax tenuimanus menunjukkan bahwa bobot lobster setelah ditransportasikan selama 24 jam turun sebesar 3,9\% dan setelah lebih dari 24 jam menjadi 4,3\%. Demikian juga dengan populasinya, semakin padat semakin besar penurunan bobotnya (Morrissy et al., 2001) .

\section{Peluang Pasar Lobster Konsumsi}

Sampai saat ini produksi lobster air tawar ukuran konsumsi masih sangat terbatas, baru ada beberapa restoran seafood di Jakarta, Bandung dan Yogyakarta yang menyajikan hidangan lobster air tawar. Namun dengan semakin berkembangnya budidaya lobster di beberapa daerah terutama di lahan tambak, produksi lobster air tawar untuk konsumsi akan meningkat. Hal ini mengingat bahwa lobster air tawar dapat hidup di air payau dengan salinitas sampai $8 \%$ (Morrissy, 1992). Peluang pasar lobster air tawar sebetulnya masih sangat terbuka, karena sejauh ini hanya Australia saja yang secara intensif membudidayakan lobster air tawar dan diekspor untuk pasar Eropa dan Amerika. Sedangkan untuk pasar Jepang, Taiwan, Hongkong dan Singapura masih sangat terbuka.

Harga lobster sangat bervariasi tergantung pada ukurannya, semakin besar ukuran lobster semakin mahal harganya. Harga lobster air tawar di Indonesia untuk konsumsi dengan ukuran kecil 30 ekor $/ \mathrm{kg}$ atau berat sekitar 30-35 g berkisar antara Rp.100.000,- sampai Rp.150.000,-. Sedangkan di Australia lobster diperdagangkan dalam berbagai ukuran dengan harga yang bervariasi sesuai ukurannya.

\section{PENUTUP}

Budidaya lobster air tawar yang sudah dikembangkan oleh masyarakat di beberapa daerah perlu didukung oleh pemerintah, sehingga produksi lobster air tawar untuk konsumsi semakin meningkat. Pemanfaatan tambak udang dan kolam dapat mendorong berkembangnya budidaya lobster air tawar secara intensif. Diharapkan nantinya produksi 
lobster air tawar melimpah seperti halnya udang vaname, sehingga komoditas ini semakin memasyarakat dan menjadi sajian prestisius seperti halnya lobster air laut.

\section{DAFTAR PUSTAKA}

Anonymous. 2007. Pomona aquaculture. http:// www.pamona spider web.com.au Diakses tanggal 1 Maret 2007. $2 \mathrm{pp}$.

Berka, R. 1986. The transportation of live fish. A Riview. EIFAC Tech. Pap, FAO (48), 52 pp.

Lawrence, C. 2001. Yabbies (Cherax albidus). A Handbook for Farmers and Investors. Fisheries Department of WA. $6 \mathrm{pp}$.

Morrissy, N.M. 1992. Introduction to Moron and Other Freshwater Crayfish Farming. Fishiries Deparment of WA. 36 pp.

Morrissy, N., Walker, P., Fellows, C. and More, W. 2001. An Investigation of Weight Loss of Morron (Cherax fenuimanus) During Live Transportation to Market.
Western Australian Marine Research Laboratories. $2 \mathrm{pp}$.

Suryaningrum, Th. D., Wibowo, S. dan Utomo, B.S.B. 2001. Pengembangan sistem biofiltrasi untuk mempertahankan mutu air pada penampungan lobster hijau pasir (Panulirus humarus) hidup dengan rak bertingkat. J. Penel. Perik. Indonesia. 7 (4) p. 62-73.

Suryaningrum, Th. D., Wibowo, S., Muljanah, I., Rosmawaty, P., Hastarini, E., Syamdidi. dan Ikasari, D. 2006. Riset penanganan dan transportasi ikan hidup air tawar. Laporan Teknis. Balai Besar Riset Pengolahan Produk dan Bioteknologi Kelautan dan Perikanan.

Wibowo, S., Suryaningrum, Th.D., Muljanah, I., Peranginangin, R., Hastarini, E., Syamdidi. dan Ikasari, D. 2005. Riset penanganan dan transportasi ikan hidup air tawar. Laporan Teknis. Pusat Riset Pengolahan Produk dan Bioteknologi Kelautan dan Perikanan. Badan Riset Kelautan dan Perikanan. 